\title{
Alcoholic liver disease as a public health problem
}

\author{
${ }^{1}$ Internal Clinic for Liver Disease Diagnosis and Treatment, Remedium s.r.o. \\ ${ }^{2}$ St. Elizabeth University of Health and Social Sciences, Bratislava, workplaces Prešov and Michalovce \\ ${ }^{3}$ Slovak Society of Practical Obesitology (SSPO), Bardejov
}

\begin{abstract}
Alcoholic liver disease (ALD) - the most common cause of advanced liver disease in Europe. The average alcohol consumption in the world is 6.13 l of pure alcohol per person older than 15 years, in Slovakia it is 13.3 l of pure alcohol per person. The rising trend of alcohol consumption among children and young people in Slovakia is alarming. According to data from the Statistical Office of the Slovak Republic, in 2011, one Slovak older than 15 years of age drank on average up to 4.5 liters of pure alcohol. In Slovakia we observe an increasing trend of alcoholic hepatitis in increasingly younger age groups, deaths including. Alcohol is the leading cause of more than 200 diseases and injuries, early work inability and mortality. Elimination of alcohol dependence would significantly contribute to the reduction of preventable liver diseases worldwide. In the article the author presents risk factors of alcoholic liver disease, brief diagnostic, clinical symptoms, treatment and patients' prognosis.

Key words: alcoholic liver disease, alcohol unit, alcohol dependence, alcohol consumption, public health.
\end{abstract}

$\mathrm{C}$ hronic diseases are the main cause of death and poor quality of life in Europe. Over 4 million people in the European Union die of chronic diseases each year (representing $87 \%$ of premature deaths in the EU). Chronic diseases are also a huge economic burden, as people in the bloom of their lives lose the ability to work.

Many chronic diseases can be prevented. Often, they are the result of smoking, harmful alcohol use, poor eating habits and insufficient physical activity. These risk factors are further multiplied by hidden socio-economic and also environmental factors [1].

Alcoholic liver disease (ALD) - the most common cause of advanced liver disease in Europe. Elimination of alcohol dependence would significantly contribute to the reduction of preventable liver diseases worldwide.

According to the WHO, on average, people in the Czech Republic, Hungary, Estonia, Lithuania, Ukraine, Latvia, Romania, Slovenia, Slovakia, Poland consume more alcohol compared to other European countries [2, 3].

The highest level of alcohol consumption in the world, which is up to 2 times the global average, is in Europe. $15 \%$ of Europeans ( $25 \%$ of men and $10 \%$ of women) consume alcohol in excessive, health threatening doses (over $40 \mathrm{~g}$ /day for men; over $20 \mathrm{~g}$ /day for women) [4].

Worldwide, alcohol is responsible for 3,8\% deaths and $4,6 \%$ of premature deaths, while in Europe it is $6,5 \%$ deaths and $11,6 \%$ of premature deaths. Alcohol causes 2.5 million deaths per year, which is more deaths than HIV, violence and tuberculosis cause all together. In terms of gender, compared to women, more men die in Europe (11\% men and $1,8 \%$ women). The social costs of alcohol-related expenditure in Europe is estimated at $€ 155.8$ billion per year [3].

Alcohol consumption in Slovakia and the incidence of alcohol-related diseases had initially increased 4 times since the second half of the 20th century. Over the past 10 years, they have been kept around the same level.
Standardized cirrhosis mortality is a very good indicator of alcohol consumption. In Europe it ranges from 3 (Latvia) to 47 (Hungary) per 100,000 men [5]. According to WHO data from 2012, in Slovakia the age-standardized cirrhosis mortality rate was for men 39.3 per 100,000 adult men per year (Hungary 57, Czech Republic 23.7, Austria 22.2) and 12 for women (Hungary 16.8, Czech Republic 9.4, Austria 6.9) [6].

Currently, in recent years, there is an alarming increasing trend in alcohol consumption among children and young people in Europe and Slovakia. The average age of a person who first had contact with an alcoholic beverage is about 10 years. As shown by figures from the Statistical Office of the Slovak Republic, young people aged 15 to 18 have an average consumption of pure alcohol of 10.2 liters per year and people over 18 years of age have 10.6 liters [3].

The problem is especially the increase of the so-called binge drinking when a young person drinks five or more glasses of alcohol in one session, while girls are catching up to boys very quickly in this [2]. According to data from the Statistical Office of the Slovak Republic, in 2011, one Slovak older than 15 years drank on average up to 4.5 liters of pure alcohol - spirits, 3.5 liters of beer and 2.2 liters of wine [2]. In Slovakia we observe an increasing trend of alcohol hepatitis in increasingly younger age categories, even in 20year-old adolescents with deaths, in both - internal and psychiatric wards.

Alcohol is a major cause of more than 200 diseases and medical conditions (diseases of other digestive organs, CNS, serious mental and social disorders), premature inability for work and mortality. In fact, there is no human body organ system that alcohol would not have a harmful effect on. Alcohol and excessive drinking negatively affect the peripheral nervous system and causes polyneuropathy. It also damages the cardiovascular system and causes ischemic heart disease, high blood pressure, cardiomyopathy [2].

Alcohol has many adverse effects on the human digestive system. Excessive drinking causes: pharyngeal 
cancer, esophageal varices, larynx cancer, chronic gastritis, gastric and duodenal ulcer, acute pancreatitis, alcohol hepatitis (liver inflammation), liver cirrhosis, liver cancer, colon cancer. Alcohol can also have a bad effect on hematopoesis, as longterm drinking can cause anemia. Drinking alcohol can also cause osteoporosis and hence disorders of the musculoskeletal system. Long-term drinking of alcohol will also affect metabolism and may also cause diabetes mellitus. Ultimately, excessive alcohol drinking also affects the reproductive system. In men it leads to impotence and sterility, in women it can cause breast cancer, irregular menstruation, fetal alcohol syndrome and in pregnant women it can also cause miscarriage [7-9].

Risk factors for alcoholic liver disease include: lifetime alcohol intake, female gender, genetic factors, race, drinking alcohol without a meal, drinking of high-concentrated and various types of alcoholic beverage, binge drinking (more than 5 units for men, or 4 units for women in a single session), malnutrition and concurrent hepatitis virus infection [10].

Alcoholism among women is increasing also because alcohol addicts do not bear such a strong social stigma of shame and because alcohol is easily available. Women are also less likely to be suspected of alcoholism, which then shows only at a later stage, they are 2 times more predisposed to liver damage (it is related to a higher proportion of total body fat, lower aldehyde dehydrogenase activity in the stomach and liver) and they are more likely to have alcohol relapse after recovery [10].

It is important to realize that a safe dose of alcohol does not exist!!!

An increased risk of cirrhosis has already been detected when consuming $25 \mathrm{~g}$ or 12-24 g of alcohol per day, for women even at a dose of $12 \mathrm{~g} /$ day.

It is necessary to explain basic concepts:

1) Standard glass (alcohol unit $=A U$ ): in most European countries it is $8-10 \mathrm{~g}$ of alcohol (WHO and America: $14 \mathrm{~g}$ of alcohol).

2) Risky drinking: daily intake of 20-40 g of alcohol for women, 40-60 $\mathrm{g}$ of alcohol for men.

3) Harmful drinking: a regular daily intake of $>40 \mathrm{~g}$ of alcohol for women, $60 \mathrm{~g}$ for men.

4) Intoxication: short-term functional impairment with impaired psychological and psychomotor performance due to alcohol.

5) Heavy episodic drinking: intake of $60 \mathrm{~g}$ of alcohol on one occasion / session (more than $5 \mathrm{AU}$ for men or more than 4 AU for women).

6) Alcohol dependence: physiological, behavioral and cognitive phenomena, when drinking alcohol has a higher priority than other types of behavior in an individual.

In Europe, one standard dose is indicated as about $10 \mathrm{~g}$ of pure alcohol. It is either: $250 \mathrm{ml}$ of beer with ABV (alcohol by volume) $5 \%$ or:

a) $125 \mathrm{ml}$ of $12 \% \mathrm{ABV}$ wine

b) $70 \mathrm{ml}$ of $18 \% \mathrm{ABV}$ dessert wine,

c) $50 \mathrm{ml}$ of $25 \% \mathrm{ABV}$ liqueur or aperitif,

d) $25 \mathrm{ml}$ of $40 \% \mathrm{ABV}$ spirit [11].
The European and American Society for the Study of Liver (EASL, AASLD) have prepared expert recommendations to improve the early diagnostics, prevention and treatment of alcoholic liver disease. In common practice, questionnaires aimed at detecting ALD are excellent diagnostic methodologies. The simplest one is the CAGE questionnaire, which consists of 4 questions. 2 or more positive responses assume alcohol dependence [7]. Another questionnaire is the AUDIT test (Alcohol Use Disorder Identification Test). It consists of 10 questions - more than 8 positive answers for men, and more than 4 for women, adolescents or men over 60 years are considered to be a positive result. For a fast screening for the detection of risky alcohol consumption, a shortened form of the AUDIT test (AUDIT-C) has been introduced. It uses the first 3 questions of the AUDIT test (if the answer to question no3 is positive, a complete AUDIT test is indicated).

Alcoholic liver disease (ALD) takes various forms. The most common and at the same time the least serious form of liver disease is steatosis. However, in $25 \%$ of the patients, it progresses to alcohol hepatitis or liver cirrhosis. The clinical symptoms are non-specific: nausea, abdominal discomfort, fatigue, in advanced stage: icterus, ascites, encephalopathy or esophageal varices bleeding [12, 13].

The key measure in the treatment of alcoholic liver disease at any stage is the absolute cessation of alcohol consumption [13]. Cooperation with a psychiatrist, psychologist, or using pharmacotherapy is very useful. The treatment includes a diet high in calories and proteins due to the risk of malnutrition in patients with advanced ALD. The primary and secondary prophylaxis of liver cirrhosis complications should not be forgotten.

From the point of view of non-pharmacological care of an ALD patient, it is recommended to give the patient brief advice, counseling or brief intervention according to the points achieved in the AUDIT test. Treatment of ALD patients must be comprehensive and requires interdisciplinary care.

With any form of alcoholic liver damage, regression is possible in case of abstinence. Liver steatosis is completely reversible after 4-6 weeks of abstinence [14]. With abstinence, more than $80 \%$ of people survive, as opposed to continuing consumers. In terms of gender, women have a worse prognosis. Less than $50 \%$ of patients survive for 2 years after the first alcohol hepatitis attack. Patient prognosis is influenced by associated complications (encephalopathy, low serum albumin, increased prothrombin time, low hemoglobin, and extensive esophageal varices).

Unfortunately, alcoholic liver disease remains the most common liver disease. The increase in alcohol consumption among children and young people, together with the rise of unemployment, are adverse factors for the country's future. Alcohol is responsible for every seventh death of men and every thirteenth death of women of working age. The issue of alcohol dependence and the associated alcoholic liver disease present a serious public health and social problem and therefore, its solving requires an interdisciplinary approach. 


\section{References}

1. BELOVIČOVÁ, M., ADAMCOVÁ-SELČANOVÁ, S. 2017. Obezita a choroby pečene. Zborník príspevkov Dni praktickej obezitológie a metabolického syndrome 15.-16.06.2017. 22-33. 1. Vyd. Studiow Miedzynarodowych i Edukacji Humanum Sp.z.o.o. ISBN 978-83-7520-221-2.

2. BLACHIER, M., LELEU, H., PECK-RADOSAVLJEVIC, M. et al. 2013. The Burden of liver disease in Europe 2013. A review of available epidemiological data. J Hepatol 2013; 58: 593-608.

3. HERETIK, A. 2013. Rizikové pitie alkoholu a jeho dôsledky. Humanita plus - špecializovaná príloha pre zdravotne postihnutých a znevýhodnených l'udí.. 2013, č. 2, str. 1-2.

4. SZÁNTOVÁ, M. 2013. Alkoholová choroba pečene. Alkoholizmus a drogové závislosti (Protialkoholický obzor). 2013; 48(1): 25-35. ISSN 0862-0350.

5. ZATONSKI, WA, SULKOWSKA, U., MANCZUK, M., REHM, J., BOFETTA, P., LOWENFELS, AB et al. 2010. Liver cirrhosis mortality in Europe, with special attention to Central and Eastern Europe. Eur Addict Res 2010; 16: $193-201$.

6. HOLOMÁŇ, J., SLOBODOVÁ, L. 2015. Cirhóza pečene a portálna hypertenzia - významné celospoločenské bremeno. Gastroentero.prax.2015; 14(1): 5-8. ISSN 1336-1473.

7. HRUŠOVSKÝ, S̆. 2015. Praktická hepatológia. 2015. Herba. Bratislava. 3. prepracované, aktualizované a doplnené vydanie.304 str. ISBN 978-80-89631-33-9.

8. NIEDERAU, C. 2015. Alcoholic Hepatitis. 585-610. In: Hepatology - a clinical textbook. Edd.: Mauss, Berg, Rockstroh, Sarrazin, Wedemeyer. Flying Publisher 2015. 6. Edition. 650 p. ISBN 978-3-924774-92-9.

9. TURČEK, M. 2013. Rizikové pitie alkoholu a škody ním spôsobené. In: Humanita plus - špecializovaná príloha pre zdravotne postihnutých a znevýhodnených l'udí.. 2013, č. 2, str. 11-12.

10. SZÁNTOVÁ, M. 2013. Alkohol a pečeň pohl'adom hepatológa. Psychiatr. prax. 2013; 14(3): 114-119. ISSN 1335-9584.

11. SEDLÁKOVÁ, D. 2013. Vláda Slovenskej Republiky proti „metle l'udstva“. In: Humanita plus - špecializovaná príloha pre zdravotne postihnutých a znevýhodnených l'udí.. 2013, č. 2, str. 5-6.

12. BELOVIČOVÁ, M. 2013. Cirhóza pečene. In: Kiňová S, Hulín I et al.: Interná medicína. Bratislava, Slovensko: Pro Litera; 2013: 699-710. ISBN 978-80-970253-9-7.

13. SZÁNTOVÁ, M. 2008. Diagnostika a liečba alkoholového poškodenia pečene. Via pract. 2008; 5 (4/5): 170-172 ISSN 1336-4790.

14. BRNKA, R. BOČA, M., HVIZDÁKOVÁ, A., ŠTEŇOVÁ, E, ŠTEŇO, B. 2008. Alkoholická choroba pečene. Súč Klin Pr 2008; 2: 34-39. ISSN 1214-7036.

Дата надходження рукопису до редакиії: 26.09.2019 р. 